ISSN: 2442-8744 (electronic); 2442-7284 (printed) Journal Homepage: https://bestjournal.untad.ac.id/index.php/Galenika

\title{
Pemodelan Farmakofor untuk Identifikasi Inhibitor Heat Shock Proteins- 90 (HSP-90)
}

\section{Pharmacophore Modeling to Identify Heat Shock Proteins-9 (HSP-90) Inhibitors}

\author{
Muhammad Arba $^{1 *}$, Arfan $^{1}$, Ayu Trisnawati ${ }^{2}$, Desi Kurniawati $^{2}$ \\ 1 *Fakultas Farmasi, Universitas Halu Oleo, Kendari, Indonesia, 93232 \\ ${ }^{2}$ Jurusan Kimia, Universitas Halu Oleo, Kendari, Indonesia.
}

E-mail: muh.arba@uho.ac.id

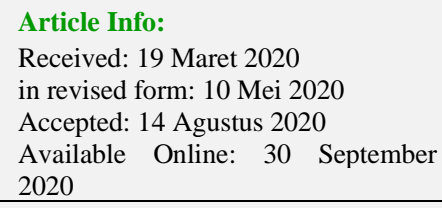

\section{Keywords:}

Pharmacophore

Heat Shock Protein-90

Molecular Docking

Virtual Screening

Corresponding Author:

Muhammad Arba

Fakultas Farmasi

Universitas Halu Oleo

Kendari

93232

Indonesia

email: muh.arba@uho.ac.id

\begin{abstract}
Heat shock proteins-90 (HSP-90) is a protein that plays an important role in the life cycle of normal and cancer cells for their self protection from thermal stress, oxidative damage, and cell hypoxia. Inhibition of HSP90 is one way to suppress the growth of cancer cells. In this study, pharmacophore modeling and molecular docking were conducted to identify hit compounds as inhibitors of HSP-90. The pharmacophore feature consists of three hydrogen bond acceptors, one hydrogen bond donor and one hydrophobic feature with Area Under Curve of Receiver Operating Characteristics (AUCROC) is 0.5 and the Goodness of Hit $(\mathrm{GH})$ value is 0.752 . Screening in the ZINC database generated 1,500 hit compounds, were subjected to molecular docking to determine their binding energy and interactions with HSP-90. The range of binding energy (E) of all hit compounds is -5.68 to $12.24 \mathrm{kcal} / \mathrm{mol}$ and there are four best hit compounds namely lig_543, lig_527, lig_1337 and lig_337, when compared to native ligands (PU2, E=$8.25 \mathrm{kkal} / \mathrm{mol}$ ) based on the binding energy and orientation, which indicate their potential as new HSP-90 inhibitors.
\end{abstract}

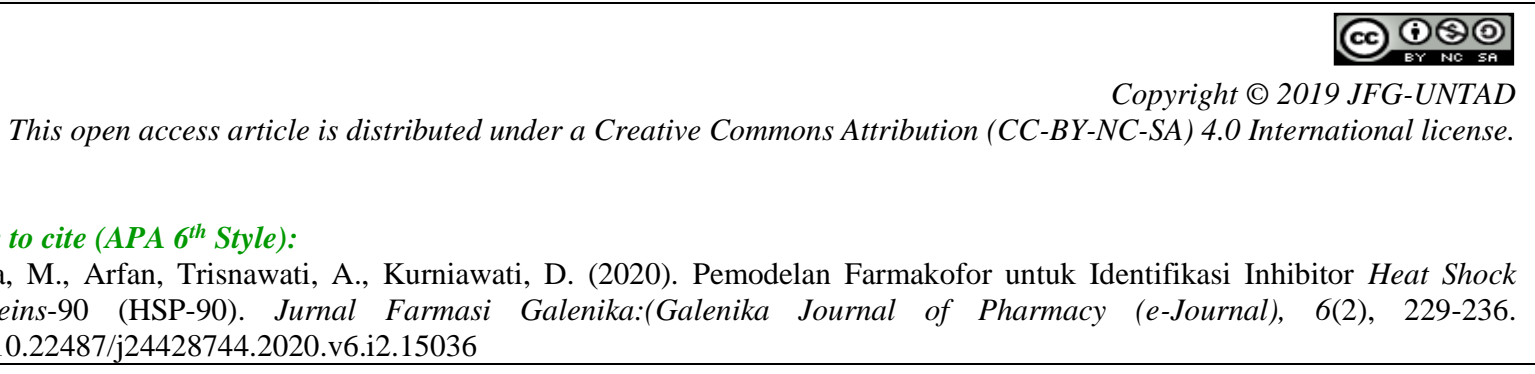




\section{ABSTRAK}

Heat shock proteins-90 (HSP-90) merupakan protein yang berperan penting dalam siklus kehidupan sel normal dan sel kanker yang berfungsi sebagai pelindung diri dari stres termal, kerusakan oksidatif, dan hipoksia sel. Penghambatan HSP-90 menjadi salah satu cara untuk menghambat perkembangan sel kanker. Pada penelitian ini, pemodelan farmakofor dan penambatan molekuler telah dilakukan untuk mengidentifikasi senyawa hit yang berpotensi menghambat HSP-90. Fitur farmakofor terdiri dari tiga akseptor ikatan hidrogen dan satu donor ikatan hidrogen dan satu fitur hidrofobik dengan Area Under Curve dari Receiver Operating Characteristic (AUC-ROC) sebesar 0,5 dan nilai Goodness of Hit (GH) sebesar 0,752. Skrining terhadap database ZINC menghasilkan sebanyak 1.500 senyawa hit yang kemudian dilakukan penambatan molekuler untuk mengetahui energi ikatan dan interaksi mereka terhadap HSP-90. Energi ikatan (E) dari semua senyawa hit berkisar antara 5,68 sampai $-12,24 \mathrm{kkal} / \mathrm{mol}$ dan terdapat empat senyawa hit terbaik yaitu lig_543, lig_527, lig_1337 dan lig_337, bila dibandingkan dengan ligan alami (PU2, E=-8,25 kkal/mol) berdasarkan energi ikatan dan orientasinya yang mengindikasikan potensi senyawa hit tersebut sebagai penghambat HSP-90 yang baru.

Kata kunci: Farmakofor, Heat Shock Protein-90, Penambatan Molekuler, Skrining Virtual.

\section{PENDAHULUAN}

HSP merupakan sekelompok protein yang terdapat dalam semua bagian perkembangan makhluk hidup serta memainkan peranan penting dalam etiologi dari banyak penyakit. Pada kanker, HSP juga terlibat dalam diferensiasi dan proliferasi, invasi serta metastasis sel kanker. Adanya rangsangan seperti stress oksidatif dan termal, perubahan kadar glukosa dan $\mathrm{pH}$, adanya inflamasi serta hambatan oksigenasi dalam sel menyebabkan HSP menjadi aktif (Juliati et al., 2015).

HSP-90 adalah salah satu tipe HSP yang bertindak untuk melindungi sel ketika mengalami stres akibat adanya kenaikan suhu yang jumlahnya akan meningkat hingga 6\% dari total protein seluler. Selain itu, HSP-90 juga melindungi protein yang kurang stabil yang dihasilkan oleh mutasi DNA (Chen et al., 2005). Penghambatan HSP-90 dapat menginduksi terjadinya apoptosis sel-sel yang abnormal dan dapat menghambat metastasis sel kanker.

Penghambat HSP-90 yang terkenal dan ampuh adalah deldanamisin (GA), namun perkembangan evaluasi klinis GA belum dilanjutkan karena sifat hepaktoksisitas dan kelarutan dalam air yang buruk (Kim et al., 2011). Turunan GA yang telah dilaporkan yang memiliki kemampuan yang baik dalam menghambat HSP-90 sebagai faktor antiangiogenik dalam sel tumor yakni 17-allylamino 17demethoxygeldanamycin (17-DMAG) (Kaur et al., 2004). 17-DMAG merupakan senyawa stabil yang larut dalam air, namun efek terapeutiknya telah dihentikan karena masih memiliki efek samping terhadap organ lain (Egorin et al., 2002). Oleh karena itu, dengan penggunaan metode skrining virtual untuk mengidentifikasi senyawa yang dapat menghambat HSP-90 dapat menjadi salah satu solusinya.

Skrining virtual merupakan salah satu metode yang terdapat dalam desain obat berbantukan komputer yang berperan dalam penemuan senyawa hit baru (Kumalo \& Soliman, 2015; Arba et al., 2018). Desain obat berbantukan komputer terdiri atas desain obat berbasis struktur dan berbasis ligan (Arba, 2019). Pada penelitian ini, dilakukan pemodelan farmakofor yang merupakan desain obat berbasis ligan untuk mengembangkan model farmakofor yang dapat digunakaan untuk menyeleksi senyawa hit baru terhadap basis data yang mengandung sejumlah besar senyawa serta dilakukan studi penambatan molekuler untuk mengetahui orientasi pengikatan senyawa hit tersebut terhadap protein HSP-90. 


\section{METODE PENELITIAN}

\section{Alat dan Bahan}

Alat yang digunakan dalam penelitian yaitu perangkat keras (hardware) berupa Note book Acer Aspire ES 11 dengan spesifikasi Intel ${ }^{\circledR}$ Celeron ${ }^{\circledR}$ Processor $\mathrm{N} 3350$, intel ${ }^{\circledR}$ HD Graphics, 2 gigabyte DDR3 L memory, 500 gigabyte. Perangkat lunak (software) berupa AutoDockTools 1.5.6, LigandScout Advance 4.3, iDock, Discovery Studio Visualizer dan website Pharmit (http://pharmit.csb.pitt.edu). Bahan yang digunakan dalam penelitian yaitu struktur 3D HSP-90 diunduh dari Protein Data Bank (http://www.rcsb.org/pdb/) dengan PDB ID 1UYG serta 125 senyawa aktif dan 4940 decoy yang diperoleh dari Directory of Useful Decoys: Enhanched (DUD-E) (http://www.dude.docking.org/) (Mysinger et al., 2012).

\section{Metode}

Farmakofor dibangun dari struktur PU2 yang merupakan ligan alami dari HSP-90 menggunakan LigandScout Advanced 4.3 (Wolber \& Langer, 2005). Farmakofor merupakan fitur struktur dari suatu senyawa dan posisinya dalam ruang tiga dimensi yang berperan dalam pengiktan senyawa yang optimal secara spesifik pada target protein (Dror et al., 2009). Model farmakofor kemudian divalidasi terhadap 125 senyawa aktif dan 4940 decoy yang diperoleh dari DUD-E, kemudian dilakukan skrining virtual terhadap database ZINC pada website Pharmit (http://pharmit.csb.pitt.edu) (Irwin et al., 2012).

Penambatan molekuler dilakukan menggunakan iDock software (Li et al., 2012). Protein dipreparasi dengan menghilangkan molekul air dan dilakukan penambahan muatan Kollman menggunakan AutoDockTools 1.5.6 software (Morris et al., 2009; Arba et al., 2019).

Sisi aktif dari protein diatur dengan mencontoh posisi ligan alami dengan koordinat center $\mathrm{x}=3,65$, center $\mathrm{y}=13,51$ dan center $\mathrm{z}=24,274$. Ukuran grid box yang digunakan sebesar $40 \mathrm{x} 40 \mathrm{x} 40 \AA$ dengan point spacing $0,375 \AA$. Grid box merupakan ukuran ruang tiga dimensi dari suatu target protein yang menjadi tempat dilakukannya penambatan molekul. Hasil dari penambatan molekul kemudian divisualisasi menggunakan Discovery Studio Visualizer.

\section{HASIL DAN PEMBAHASAN}

Fitur farmakofor dari PU2 terdiri dari 11 fitur yaitu 1 cincin aromatik, 5 akseptor ikatan hidrogen, 3 donor ikatan hidrogen, dan 1 fitur hidrofobik. Lebih lanjut, model farmakofor dikembangkan dengan menggunakan kombi nasi fitur-fitur tersebut dan Tabel 1 menampilkan model farmakofor yang dihasilkan beserta nilai Area Under Curve dari Receiver Operating Characteristic (AUC-ROC).

Model farmakofor yang baik harus memiliki nilai AUC-ROC yang lebih besar dari 0,5 serta nilai GH yang lebih dari 0,7 (Arba, 2019). Model farmakofor PU2-3 memiliki nilai AUC100\% sebesar 0,9, namun nilai GH 0,21 tidak memunhi syarat validasi. Dengan demikian dipilih model PU2-1 dengan AUC100\% sebesar 0,5 dan nilai GH sebesar 0,752. Nilai AUC-ROC yang mendekati 1 menunjukkan bahwa model farmakofor semakin baik dan mampu membedakan antara senyawa aktif dengan decoy (senyawa yang tidak aktif/pengecoh). Nilai GH diperoleh dari penggabungan sensitivitas (Se), spesifitas (Sp) dan yield of actives (YA). Sensitivitas menggambarkan kemampuan suatu model farmakofor untuk mengenali senyawa aktif. Spesifitas menggambarkan kemampuan dari model farmakofor untuk mengenali senyawa tidak aktif sebagai senyawa tidak aktif. Yield of actives menunjukkan kemampuan model farmakofor untuk mengenali senyawa aktif dalam jumlah senyawa hit yang diperoleh dari database. Berikut rumus penentuan nilai GH (Arba, 2019):

$$
\mathrm{GH}=\left(\frac{4}{4} Y A+\frac{1}{4} S e\right) S p
$$


Tabel 1. Model Farmakofor ligan alami (PU2) dari protein HSP-90

\begin{tabular}{|c|c|c|c|c|}
\hline $\begin{array}{c}\text { Kode } \\
\text { Senyawa }\end{array}$ & Model farmakofor & $\begin{array}{c}\text { Fitur } \\
\text { Farmakofor }\end{array}$ & $\begin{array}{c}\text { Goodness of } \\
\text { Hit } \text { (GH) }\end{array}$ & $\mathbf{A U C}_{100 \%}$ \\
\hline PU2-1 & HOH2155A & $\begin{array}{c}1 \text { hidrofobik, } 3 \\
\text { akseptor ikatan } \\
\text { hydrogen, } 1 \\
\text { donor ikatan } \\
\text { hidrogen }\end{array}$ & 0,752 & 0,50 \\
\hline PU2-2 & $\int_{\text {marezs }}$ & $\begin{array}{c}1 \text { hidrofobik, } 3 \\
\text { akseptor ikatan } \\
\text { hidrogen, } 1 \\
\text { donor ikatan } \\
\text { hidrogen }\end{array}$ & 0,151 & 0,04 \\
\hline PU2-3 & Letiona & $\begin{array}{c}1 \text { hidrofobik, } 3 \\
\text { akseptor } \\
\text { hidrogen, } 1 \\
\text { donor ikatan } \\
\text { hidrogen }\end{array}$ & 0,210 & 0,90 \\
\hline
\end{tabular}

Selanjutnya, skrining virtual dilakukan dengan menggunakan model farmakofor yang telah divalidasi menggunakan website Pharmit menghasilkan sebanyak 1500 senyawa hit. Penambatan molekuler bertujuan untuk memprediksikan modus pengikatan atau interaksi antara ligan dan protein beserta energi ikatan mereka (Zhao et al., 2020). Validasi proses penambatan molekuler dilakukan dengan penambatan ulang ligan alami PU2 dan protein yang diperoleh dari protein data bank. Validasi ini bertujuan untuk menilai kemampuan proses penambatan molekul dalam menghasilkan konformasi ligan yang mirip dengan hasil eksperimen. Proses penambatan molekul yang valid dapat dinilai parameter Root Mean Square Deviation (RMSD) atom-atom berat antara konformasi penambatan molekul dengan hasil eksperimen (kristalografi) maksimal $2 \AA$ (Ravindranath et al., 2015; Musoev et al., 2019). Penambatan molekuler dilakukan untuk semua ligan termasuk ligan alami (PU2). Penambatan ulang PU2 menghasilkan energi pengikatan sebesar $-8,25 \mathrm{kkal} / \mathrm{mol}$ dengan nilai RMSD sebesar 0,6316 $\AA$ (Gambar 1). Pose/konformasi hasil penambatan dari PU2 menunjukkan tiga ikatan hidrogen dengan Asp93, Gly97 dan Thr184 serta memiliki enam interaksi hidrofobik dengan Ser52, Ile96, Leu103, Ala111, Val136 dan Val150. 


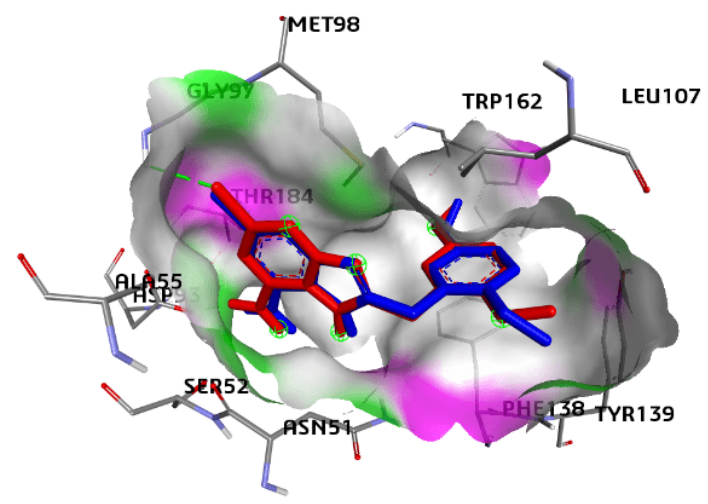

Gambar 1. Superposisi antara konformasi $x$-ray (merah) dengan hasil docking (biru) dengan garis putus-putus berwarna hijau menunjukkan ikatan hidrogen.

Penambatan molekuler 1500 senyawa hit menghasilkan konformasi dengan energi ikatan antara -5,68 sampai -12,24 kkal/mol. Empat senyawa hit terbaik dalam hal konformasi dan energi ikatan adalah lig_543 $(\mathrm{E}=-12,24 \mathrm{kkal} / \mathrm{mol}), \operatorname{lig} \_527(\mathrm{E}=-11,31 \mathrm{kcal} / \mathrm{mol}), \operatorname{lig} \_1337(\mathrm{E}=-11,31 \mathrm{kcal} / \mathrm{mol})$, dan lig_337 (E = -11,26 kkal/mol). Keempat senyawa hit tersebut memiliki energi ikatan yang lebih rendah bila dibandingkan dengan PU2. Energi ikatan menggambarkan afinitas atau kemampuan suatu senyawa untuk berikatan/berinteraksi dengan target protein. Nilai energi ikatan yang semakin rendah menunjukkan afinitas yang semakin kuat. Gambar 2 menampilkan struktur senyawa hit terbaik hasil skrining:

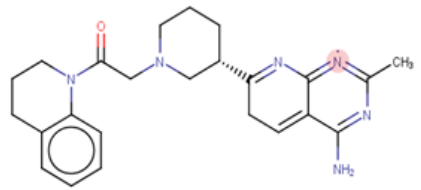

Lig_543

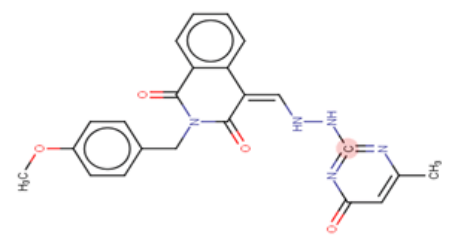

Lig_1337

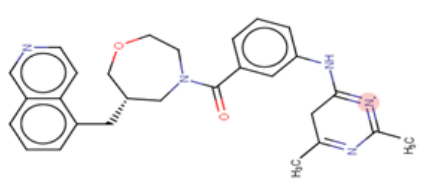

Lig_527

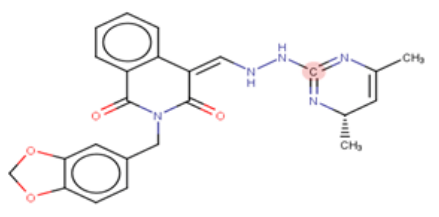

Lig_337

Gambar 2. Struktur senyawa hit terbaik

Interaksi molekul-molekul hit terjadi di sisi aktif dari HSP-90 melalui ikatan hidrogen dan interaksi hidrofobik (Gambar 3). Ikatan hidrogen dengan Gly97 dan Thr184 yang diamati pada struktur kristalografi PU2, juga terdapat pada pengikatan Lig_1337. Selain itu, ikatan hidrogen dengan Asn51 juga diamati dalam pengikatan Lig_527. Lig_1337 dan Lig_337 berinteraksi melalui ikatan hidrogen dengan Tyr139. Interaksi hidrofobik dengan residu Leu103 pada struktur kristalografi ligan alami (PU2), teramati pula pada lig_543 dan lig_337. Selain itu, residu Val130 dan Val150 juga memiliki interaksi dengan lig_1337 dan lig_337. Gambar 4 menunjukkan interaksi lig_543, lig_527, lig_1337 dan Lig_337 terhadap HSP-90. 


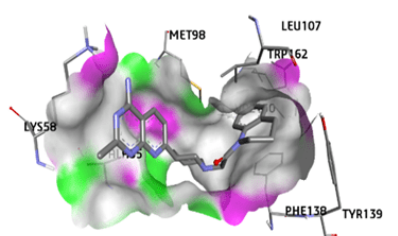

Lig_543

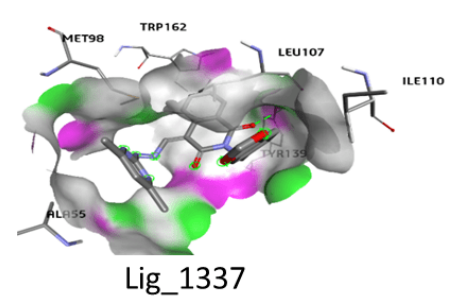

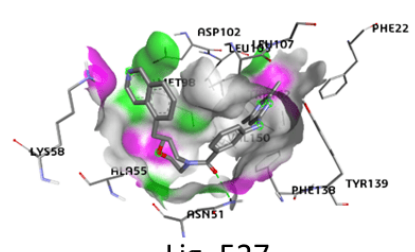

Lig_527

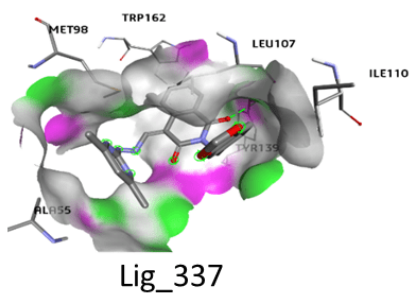

Gambar 3. Interaksi dari Lig_543, Lig_527, Lig_1337 dan Lig_337 terhadap HSP-90 dengan garis putus-putus berwarna hijau menunjukkan ikatan hidrogen.

Berdasarkan konformasi dan nilai energi ikatan dari 4 senyawa hitu tersebut mengindikasikan bahawa keempat senyawa tersebut berpotensi sebagai inhibitor HSP90 deengan modus pengikatan yang serupa dengan ligan alami PU2.

\section{KESIMPULAN}

Dalam penelitian ini, pemodelan farmakofor dilakukan untuk mengidentifikasi senyawa hit yang berpotensi menghambat HSP-90. Model farmakofor yang dibangun kemudian digunakan untuk menskrining senyawa hit baru pada database ZINC yang berisi lebih dari 13 juta senyawa. Ditemukan empat senyawa hit (Lig_543, Lig_527, Lig_1337 dan_Lig_337) yang memiliki afinitas lebih kuat bila dibandingkan dengan ligan alami (PU2). Dengan demikian keempat senyawa tersebut diusulkan diverifikasi sebagai inhibitor HSP90 yang potensial melalui studi eksperimen in vitro dan in vivo.

\section{UCAPAN TERIMAKASIH}

Ucapan terima kasih kepada Universitas Halu Oleo atas dukungan dalam penelitian ini melalui Penelitian Dasar Unggulan Perguruan Tinggi.

\section{DAFTAR PUSTAKA}

Arba, M. (2019). Buku Ajar Farmasi Komputasi. Yogyakarta: Deepublish.

Arba, M., Azali, H., Ombe, S., Armid, A., \& Usman, I. (2019). 3D-QSAR, Molecular Docking and Dynamics Simulation of Difluorophenol Pyridine Derivatives as RSK2 Inhibitor. J. Appl. Pharm. Sci., 9(6), 001-009.

Arba, M., Nur-Hidayat, A., Surantaadmaja, S. I., \& Tjahjono, D. H. (2018). Pharmacophore-based Virtual Screening for Identifying $\beta 5$ Subunit Inhibitor of 20S Proteasome. Computational Biology and Chemistry, 77, 64-71.

Chen, B., Piel, W. H., Gui, L., Bruford, E., \& Monteiro, A. (2005). The HSP90 Gen Family in Human Genom: Their Different Wawasan and Evolution. Genomics, 86(6).

Dror, O., Schneudman-Duhovny, D., Inbar, Y., Nussinov, R., \& Wolfson, H. J. (2009). Novel Approach for Efficient Pharmacophore-Based Virtual Screening: Method and Applications. $J$. Chem. Inf. Model, 49, 2333-2343. 
Egorin, M. J., Lagattuta, T. F., \& Hamburger, D. R. (2002). Pharmacokinetics, Tissue Distribution and Metabolism of 17-(Dimethylaminoethylamino)-17-Demethoxygeldanamycin (NSC 707545) in CD2F1 Mice and Fischer 344 Rats. Cancer Chemother Pharmacol, 49, 7-19.

Irwin, J. J., Sterling, T., Mysinger, M. M., Bolstad , E. S., \& Coleman, R. G. (2012). ZINC: A Free Tool to Discovery Chemistry for Biology. J. Chem. Inf. Model, 52(7), 1757-1768.

Juliati, F., Brahmana, A., \& Dyah, F. (2015). Hubungan antara Ekspresi Hsp27 dan Hsp70 dengan Derajat Diferensiasi dan Angka Ketahanan Hidup Dua Tahun pada Penderita Kanker Endometrium Tipe I Pasca-Pembedahan di RSUD Dr. Soetomo. Indonesian Journal of Cancer, 9(2).

Kaur, G., Belotti, D., Burger, A. M., Fisher-Nielson, K., Borsotti, P., Riccardi, F., . . Giayazzi, R. (2004). Antiangiogenic Properties of 17-(Dimethylaminoethylamino)-17Demethoxygeldanamycin: An Orally Bioavailable Heat Shock Protein 90 Modulator. Clin Cancer Res, 10, 4813-4821.

Kim, H. Y., J.Park, K. H., Lee, D. U., Kwak, Y. S., \& Kim, S. M. (2011). The Future of Thoracoscopic Lobectomy in Lung Cancer. Asian Cardiovasc Thorac Ann, 28(2).

Kumalo, H. M., \& Soliman, M. E. (2015). Per-Residue Energy Footprints-Based Pharmacophore Modeling as an Enhanced in Silico Approach in Drug Discovery: A Case Study on the Identification of Novel b-Secretase 1 (BACE1) Inhibitors as AntiAlzheimer Agents. Cell. Mol. Bioeng., 9(1), 175-189.

Li, H., Leung, K., \& Wong, M. (2012). Idock: A Multithreaded Virtual Screening Tool for Flexible Ligand Docking. 2012 IEEE Symposium on Computational Intelligence in Bioinformatics and Computational Biology (CIBCB).

Morris , G. M., Huey, R., Lindstorm, W., Sanner , M. F., Belew, R. K., Goodsell, D. S., \& Olson, A. J. (2009). AutoDock4 and AutoDock Tools4: Automated Docking with Selective Receptor Flexibility. J. Comput. Chem., 30(16), 2785-2791.

Mussev, A., Sodik, N., Zhuhong Y., \& Hongwei G. (2019). Discovery of Novel DPP-IV Inhibitors as Potential Candidates for the Treatment of Type 2 Diabetes Mellitus Predicted by 3D QSAR Pharmacophore Models, Molecular Docking and De Novo Evolution. Molecules, 24(16), 2870.

Mysinger, M. M., Charcia, M., Irwin, J. J., \& Shoichet , B. K. (2012). Directory of Useful Decoys, Enhanced (DUD-E): Better Ligands and Decoys for Better Benchmarking. J. Med. Chem, 55(14), 6582-6594.

Ravindranath, P. A., Forli, S., Goodsell, D. S., Olson, A. J., \& Sanner, M. F. (2015). AutoDockFR: Advances in Protein-Ligand Docking with Explicitly Specified Binding Site Flexibility. PLOS Computational Biology, 11(12), e1004586.

Wolber, G., \& Langer, T. (2005). LigandScout: 3-D Pharmacophores Derived from Protein-Bound Ligands and Their Use as Virtual Screening Filters. J. Chem. Inf. Model, 45(1), 160-169. 
Zhao, J., Cao, Y., \& Zhang, L. (2020). Exploring the Computational Methods for Protein- Ligand Binding Site Prediction. Computational and Structural Biotechnology Journal. 8, 417-426. 